\title{
NATURAL NITROGEN-15 ABUNDANCE OF SOIL AND PLANT SAMPLES
}

\author{
D. A. RENNIE, E. A. PAUL, and L. E. JOHNS \\ University of Saskatchewan, Saskatoon, Sask. Contribution of Department of Soil Science, \\ Saskatchewan; Institute of Pedology publication no. RI62, received 21 July 1975 , \\ accepted 8 Dec. 1975.
}

Rennie, D. A., Paul, E. A. And Johns, L. E. 1976. Natural nitrogen-15 abundance of soil and plant samples. Can. J. Soil Sci. 56: 43-50.

\begin{abstract}
Nitrogen isotope analysis of total soil $\mathrm{N}$ and soil-derived nitrate for nine selected Chernozemic and Luvisolic Ap horizons showed mean $\delta_{\mathrm{a}}{ }^{15} \mathrm{~N}$ values based on atmospheric abundance of 8.8. Luvisolic soils were characterized by a relatively low level of the heavier isotope. Isotope enrichment of the total $\mathrm{N}$ reached a maximum in the lower B horizon. Subsoil nitrate (180-cm depth) had a $\delta_{\mathrm{a}}{ }^{15} \mathrm{~N}$ value $1 / 3$ that of the Ap horizon. The $\delta_{\mathrm{a}}{ }^{15} \mathrm{~N}$ of subsurface soil horizons containing residual fertilizer $\mathrm{N}$ were low $(-5.2)$ compared to the surface horizon (7.0). The $\delta_{\mathrm{a}}{ }^{15} \mathrm{~N}$ of $\mathrm{NH}_{4}-\mathrm{N}$ in commercial fertilizers is close to that of atmospheric- $\mathrm{N}$ whereas the $\mathrm{NO}_{3}-\mathrm{N}$ has higher values. The data suggest that variations in $\delta^{15} \mathrm{~N}$ abundance between horizons of the same soil, or between different soils, may be of real use in evaluating stresses which have been placed in the nitrogen cycle due to man's activities in the past. Similarly, differences in ${ }^{15} \mathrm{~N}$ abundance of soil, legume and air samples may provide an integrated estimation of symbiotic nitrogen fixation under field conditions. More detailed understanding of biological and other processes which control the $\mathrm{N}$ isotope concentrations must be obtained before the data reported can be further interpreted.
\end{abstract}

L'analyse isotopique de l'azote total du sol et des nitrates du sol dans neuf horizons Ap chernozémiques et luvisoliques a révélé des valeurs moyennes $\delta_{\mathrm{a}}{ }^{15} \mathrm{~N}$ de 8.8 basées sur l'abondance relative de cet isotope dans l'atmosphère. Les Luvisols ont manifesté un niveau relativement faible de l'isotope lourd. La concentration d'isotope a atteint un maximum dans la couche inférieure de l'horizon B. Les nitrates du sous-sol (profondeur de $180 \mathrm{~cm}$ ) ont donné des valeurs $\delta_{\mathrm{a}}{ }^{15} \mathrm{~N}$ équivalent au tiers de celles des horizons Ap. Dans les horizons de profondeur contenant du N résiduel provenant de la fumure, les valeurs étaient faibles (-5.2) par rapport à celles de l'horizon $\mathrm{Ap}(7.0)$. Les valeurs $\delta_{\mathrm{a}}{ }^{15} \mathrm{~N}$ de $\mathrm{N}$ ammoniacal des engrais commerciaux sont voisines de celle du $\mathrm{N}$ atmosphérique, celle de $\mathrm{N}$ nitrique étant plus forte. Ces données font ressortir l'utilité réelle des variations de la proportion de ${ }^{15} \mathrm{~N}$ entre les horizons d'un même sol et entre différents sols pour évaluer les contraintes imposées au cycle de $\mathrm{N}$ par les activités anthropiques passées. De même, des différences dans l'abondance de ${ }^{15} \mathrm{~N}$ dans des échantillons de sol, de légumineuses et d'air peuvent fournir une estimation intégrée de la fixation azotée symbiotique dans les conditions de culture au champ. Une interprétation plus en profondeur des données présentées suppose une compréhension plus détaillée des processus biologiques et autres qui commandent les proportions de l'isotope de $\mathrm{N}$.

Natural variations in ${ }^{15} \mathrm{~N}$ abundance of a range of nitrogen-cóntaining substances have been established. Twenty natural substances, including forest soil, coal, peat and pitchblend had a per mil enrichment of ${ }^{15} \mathrm{~N}$ compared to reference standards ranging from -13.0 to 953 (Hauck 1973). Can. J. Soil Sci. 56: 43-50 (Feb. 1976)
Generally, however, the ${ }^{15} \mathrm{~N}$ content of biosphere nitrogen is restricted to a range of $\pm 10 \delta^{15} \mathrm{~N}$ units.

There is good reason to assume that the variations in the natural abundance of ${ }^{15} \mathrm{~N}$ can be used to obtain qualitative and perhaps quantitative information on the relationships among $\mathrm{N}$ cycle processes 
under various environmental conditions. Whether such variations can be used for quantifying the effects of environmental changes on the nitrogen cycle both in terrestrial and marine systems over long- or short-term periods must await an understanding of the isotope fractionation accompanying the nitrogen transformations in the abiotic-biotic systems involved (Hauck 1973; Cline 1973).

A number of biologically induced isotope effects have been reported. Biological discrimination against the heavier $\mathrm{N}$ isotope $\left({ }^{15} \mathrm{~N}\right)$ occurs during the fixation of atmospheric $\mathrm{N}_{2}$ by bacteria (Hoering 1955; Delwiche and Steyn 1970). Nitrogen isotope fractionation has been reported to occur during denitrification (Wellman et al. 1968; Cline 1973) and during the oxidation of ammonia to nitrate (Delwiche and Steyn 1970). Certain soil organisms which preferentially utilize $\mathrm{NH}_{4}-\mathrm{N}$ also discriminate against the heavier nitrogen isotope, with the result that the $\mathrm{NH}_{4}-\mathrm{N}$ remaining in the media becomes enriched with respect to ${ }^{15} \mathrm{~N}$, providing, of course, assimilation is not completed. Chemical changes such as $\mathrm{NH}_{3}$ volatilization and ion exchange show similar effects.

The various isotope effects occurring in the soil usually result in positive $\delta^{15} \mathrm{~N}$ values for surface horizons. This is reflected in the data reported in the literature (Cheng et al. 1964; Bremner et al. 1966; Delwiche and Steyn 1970; Kohl et al. 1971; Edwards 1973; Feigin et al. 1974a,b). However, some forested soils show negative deviations (Riga et al. 1971), and Bremner and Tabatabai (1973) have reported a mean $\delta{ }^{15} \mathrm{~N}$ value of -0.2 for 16 surface soil samples.

The study reported in this paper was carried out to determine ${ }^{15} \mathrm{~N}$ enrichment of total $\mathrm{N}$ and soil nitrates in selected soil profiles, fertilizers and plant samples. We documented the range of ${ }^{15} \mathrm{~N}$ abundance obtained on Brown, Dark Brown, and Black Chernozemic grassland soils, and also the Luvisolic-forested soils. Limited informa- tion is presented on changes in $\delta{ }^{15} \mathrm{~N}$ down to depths of $270 \mathrm{~cm}$.

\section{MATERIALS AND METHODS}

\section{Soils}

With the exception of profile samples from an irrigated field fertilizer experiment and a few from land seeded to tame grass, soil samples were from summer-fallowed fields which had never received nitrogen fertilizer.

Plant and soil samples, taken from a field plot experiment on a Chernozemic Black soil, were assayed for ${ }^{15} \mathrm{~N}$ abundance. The barley (Hordeum vulgare) and faba bean (Vicia faba) grain and straw, and a representative sample of the surface soil, were dried at room temperature and ground to pass a 2-mm sieve.

\section{${ }^{15} \mathbf{N}$ Assay}

Analytical and ${ }^{15} \mathrm{~N}$ assay procedures used are described by Rennie and Paul (1971). The analysis used for total $\mathrm{N}$, including nitrate and nitrite, is a modified semimicro version of the method of Bremner (1965). The total $\mathrm{N}$ assay involved a pretreatment with acidified permanganate to oxidize nitrite to nitrate, followed by reduced iron and sulfuric acid to reduce the nitrate to ammonium. Kjeldahl digestion was used to convert organic nitrogen to the ammonia form. The ammonia evolved by the addition of $40 \%$ sodium hydroxide was steam-distilled using a quick-fit steam distillation apparatus with 100-ml sample flasks. Cross contamination was avoided by distilling $15 \mathrm{ml}$ of $95 \%$ ethanol after each steam distillation to flush the distillation head and condenser.

Nitrate extraction was carried out using a 1:5 soil:water ratio. High speed centrifugation followed by filtration through glass fiber paper was employed to separate the soil from the solution. The extract from $150 \mathrm{~g}$ of soil was concentrated, using a rotary evaporator, to 25 $\mathrm{ml}$. Conversion of the nitrate $\mathrm{N}$ to ammonia followed the procedure of Bremner and Keeney (1966).

The ammonia, from either the total $\mathrm{N}$ or nitrate $\mathrm{N}$ samples, was converted to $\mathrm{N}_{2}$ gas by oxidation with alkaline hypobromite solution using a "Y"-tube reaction vessel. The nitrogen-isotope ratio procedure is adapted to an Atlas GD150 mass spectrometer equipped with double inlet and collector system. 


\section{Calculations}

The proportion of stable isotopes occurring in nature is generally expressed as a function of the ratio of the isotopes (Craig 1957; Campbell et al. 1967; Cline 1973). Hauck (1973) similarly defined $\delta{ }^{15} \mathrm{~N}$ as a function of $\frac{{ }^{15} \mathrm{~N}}{{ }^{14} \mathrm{~N}}$ ratios, i.e.

$\delta{ }^{15} \mathrm{~N}=\frac{\frac{{ }^{15} \mathrm{~N}}{{ }^{14} \mathrm{~N}} \text { (sample) }-\frac{{ }^{15} \mathrm{~N}}{{ }^{14} \mathrm{~N}} \text { (standard) }}{\frac{{ }^{15} \mathrm{~N}}{{ }^{14} \mathrm{~N}} \text { (standard) }} .1000(1)$

In contrast, where ${ }^{15} \mathrm{~N}$ enriched nitrogen compounds have been used in fertilizer management and nitrogen cycling studies, the isotope concentration has customarily been reported as percent abundance of the $\mathrm{N}$, or some value derived thereof (Rennie and Paul 1971). Kohl et al. (1971) defined $\delta^{15} \mathrm{~N}$ as the per mil enrichment of $\frac{{ }^{15} \mathrm{~N}}{{ }^{15} \mathrm{~N}+{ }^{14} \mathrm{~N}}$ and compared to its enrichment in the air. Riga et al. (1971), Edwards (1973) and Bremner and Tabatabai (1973) calculated $\delta^{15} \mathrm{~N}$ in the same manner.

The $\delta{ }^{15} \mathrm{~N}$ data in this manuscript have been calculated as a function of the ${ }^{15} \mathrm{~N}$ abundance and to avoid confusion and clearly differentiate these data from those derived from isotope ratios $\left({ }^{15} \mathrm{~N} /{ }^{14} \mathrm{~N}\right)$, our data are designed as $\delta_{\mathrm{a}}{ }^{15} \mathrm{~N}$,

i.e.: $\delta_{\mathrm{a}}{ }^{15} \mathrm{~N}=$

$$
\frac{\frac{{ }^{15} \mathrm{~N}}{{ }^{14} \mathrm{~N}+{ }^{15} \mathrm{~N}} \text { (sample) }-\frac{{ }^{15} \mathrm{~N}}{{ }^{14} \mathrm{~N}+{ }^{15} \mathrm{~N}}}{\frac{{ }^{15} \mathrm{~N}}{{ }^{14} \mathrm{~N}+{ }^{15} \mathrm{~N}} \text { (atmosphere) }} .1000
$$

Jung and Svec (1958), in measuring the ${ }^{15} \mathrm{~N}$ of atmospheric $\mathrm{N}$, measured a ${ }^{14} \mathrm{~N} /{ }^{15} \mathrm{~N}$ ratio of 272 . This corrects to an abundance of 0.3663 . The reagent grade $\left(\mathrm{NH}_{4}\right)_{2} \mathrm{SO}_{4}$ had an abundance of 0.3668 compared to air designated as 0.3663 . The $\delta_{\mathrm{a}}{ }^{15} \mathrm{~N}$ of the $\left(\mathrm{NH}_{4}\right)_{2} \mathrm{SO}_{4}$ therefore was 1.4 . The standard deviation for $10 \quad\left(\mathrm{NH}_{4}\right)_{2} \mathrm{SO}_{4}$ standards run on three consecutive days was \pm $0.1 \delta_{\mathrm{a}}{ }^{15} \mathrm{~N}$.

\section{RESULTS AND DISCUSSION A Survey of Soils}

The $\delta_{\mathrm{a}}{ }^{15} \mathrm{~N}$ values for the Chernozemic and Luvisolic Ap horizons show that, on the average, identical levels of enrichment were recorded for the total soil $\mathrm{N}$ and $\mathrm{NO}_{3}-\mathrm{N}$ under field conditions (Table 1). Nitrates showed much greater variability. The values are of the same magnitude as those reported for Illinois surface soils (Kohl et al. 1971; Shearer et al. 1974), but are higher than those of 16 surface soil samples reported by Bremner and Tabatabai (1973). Cheng et al. (1964), Bremner et al. (1966), and Delwiche and Steyn (1970) report a few $\delta_{\mathrm{a}}{ }^{15} \mathrm{~N}$ values which are equivalent to the values given in Table 1.

The lowest $\delta_{\mathrm{a}}{ }^{15} \mathrm{~N}$ values for total $\mathrm{N}$ were obtained on soils which had developed under forest vegetation. This is in accord with the trends reported by Riga et al. (1971), who found that the Belgian forested samples were characterized by $\delta_{\mathrm{a}}{ }^{15} \mathrm{~N}$ in the negative range.

\section{$\delta_{\mathrm{a}}{ }^{15} \mathrm{~N}$ of Soil-derived $\mathrm{NO}_{3}-\mathrm{N}$}

The $\delta_{\mathrm{a}}{ }^{15} \mathrm{~N}$ values of the soil-derived $\mathrm{NO}_{3}-\mathrm{N}$ (Table 1) correspond to those recorded for total $\mathrm{N}$ with one significant exception, the Weyburn 1 sample. Studies reported elsewhere have indicated that the ${ }^{15} \mathrm{~N}$ enrichment of $\mathrm{NO}_{3}-\mathrm{N}$ varies widely with time, and is consistently lower than that of the total soil $\mathrm{N}$ (Feigin et al. 1974a; Delwiche and Steyn 1970; Edwards 1973). Feigin et al. (1974b) obtained constant and presumably characteristic $\delta_{a}{ }^{15} \mathrm{~N}$ values for soil-derived $\mathrm{NO}_{3}-\mathrm{N}$ after 5 wk of incubation. The $\delta_{\mathrm{a}}{ }^{15} \mathrm{~N}$ values for soil-derived $\mathrm{NO}_{3}-\mathrm{N}$ from the 21-day incubated and from field samples for two Chernozemic soils are given in Table 2. Contrary to data reported elsewhere (Delwiche and Steyn 1970; Bremner and Tabatabai 1973; Edwards 1973), the values for the $\mathrm{NO}_{3}-\mathrm{N}$ obtained on incubation were only slightly lower than those in the field samples. This reflects two environmental factors: (1) neither soil had received significant amounts of fertilizer $\mathrm{N}$ in the past; (2) the field samples were taken from summer-fallow fields (biological $\mathrm{N}$ transformation in quasiequilibrium).

The similarity between the $\delta_{\mathrm{a}}{ }^{15} \mathrm{~N}$ of total soil $\mathrm{N}$ and of $\mathrm{NO}_{3}-\mathrm{N}$ extracted from nonincubated samples from this survey, with comparison to similar data reported elsewhere, is illustrated in Fig. 1. The data 
Table 1. $\quad \delta_{\mathrm{a}}{ }^{15} \mathrm{~N}$ values for Ap horizon samples of selected soils

\begin{tabular}{|c|c|c|c|c|}
\hline \multirow[b]{2}{*}{ Soilt } & \multicolumn{2}{|c|}{ Total N } & \multicolumn{2}{|c|}{$\mathrm{NO}_{3}-\mathrm{N}$} \\
\hline & $\mu \mathrm{g} / \mathrm{g}$ & $\delta_{\mathrm{a}}^{15} \mathrm{~N}$ & $\mu \mathrm{g} / \mathrm{g}$ & $\delta_{\mathrm{a}}{ }^{15} \mathrm{~N}$ \\
\hline \multicolumn{5}{|l|}{$\begin{array}{l}\text { Brown Chernozemic } \\
\text { (Aridic Boroll) }\end{array}$} \\
\hline Sceptre hvc & 2,225 & 6.4 & - & - \\
\hline \multicolumn{5}{|c|}{$\begin{array}{l}\text { Dark Brown Chernozemic } \\
\text { (Typic Boroll) }\end{array}$} \\
\hline Sutherland $\mathrm{c}+$ & 1,990 & 8.7 & 23 & 11.0 \\
\hline Elstow cl & 2,260 & 9.5 & 17 & 9.1 \\
\hline Scott l & 1,810 & 9.6 & 13 & 8.4 \\
\hline Weyburn 1 F & 3,250 & 8.8 & 48 & 2.7 \\
\hline Asquith fl & 1,370 & 8.2 & 17 & 7.5 \\
\hline Bradwell sl-1 & 2,110 & 10.2 & 16 & 12.8 \\
\hline Bradwell sl-2§ & 1,900 & 9.4 & 23 & 10.1 \\
\hline \multicolumn{5}{|l|}{$\begin{array}{l}\text { Black Chernozemic } \\
\text { (Udic Boroll) }\end{array}$} \\
\hline Oxbow 1 & 3,120 & 8.6 & 19 & 10.9 \\
\hline \multicolumn{5}{|l|}{$\begin{array}{l}\text { Grey Luvisol } \\
\quad \text { (Cryboralf) }\end{array}$} \\
\hline Waitville 1-1 & 1,510 & 6.2 & 26 & 7.0 \\
\hline Waitville $1-2 \neq$ & 2,150 & 4.6 & - & - \\
\hline Mean $\pm \mathrm{SD} / /$ & & $8.8 \pm 1.2$ & & $8.8 \pm 2.9$ \\
\hline
\end{tabular}

$\dagger$ For further descriptions of the soils, see Canada Dep. Agric. Publ. No. 1455, 1974.

$\doteqdot$ Past fertilizer history unknown.

§Grass breaking.

//The mean values for total $\mathrm{N}$ exclude those for the Sceptre and Waitville-2 samples, as comparable $\mathrm{NO}_{3}-\mathrm{N}$ values are not available.

obtained by Feigin et al. (1974a,b) for samples which had been incubated for 29 wk and for a number of the samples reported by Bremner and Tabatabai (1973) fall essentially on the same regression line.

Edwards (1973) concluded that the problem of obtaining a representative soil sample for use in establishing the isotope content of soil-derived nitrate for field investigations in insurmountable, as there is no logical basis for choosing one incubation time over another to reflect the field environment. This observation is supported by the data he reported and by that of Bremner and Tabatabai (1973).

The data reported in this study afford a rather marked contrast to that from the Midwest, in that the $\delta_{\mathrm{a}}{ }^{15} \mathrm{~N}$ values of $\mathrm{NO}_{3}-\mathrm{N}$ mineralized under field conditions not only approximates that of total soil $\mathrm{N}$, but also

Table 2. Nitrate contents and $\delta_{\mathrm{a}}{ }^{15} \mathrm{~N}$ values for incubated vs. field samples of two Dark Brown Chernozemic soils

\begin{tabular}{lrrrr}
\hline & \multicolumn{2}{c}{ Asquith $\mathrm{fl}$} & \multicolumn{2}{c}{ Elstow cl } \\
\cline { 2 - 5 } & $\mathrm{N}$ & $\delta_{\mathrm{a}}{ }^{15} \mathrm{~N}$ & & $\begin{array}{c}\mathrm{NO}_{3}-\mathrm{N} \\
(\mu \mathrm{g} / \mathrm{g})\end{array}$ \\
\hline Total & $1, \mathrm{~g} / \mathrm{g})$ & 7.7 & 2,260 & $\delta_{\mathrm{a}}{ }^{15} \mathrm{~N}$ \\
Incubated $\dagger$ & 1,370 & 7.4 & 25 & 9.4 \\
Field Sample & 27 & 8.3 & 17 & 9.8 \\
\hline
\end{tabular}

$†$ The samples were leached prior to a 21 -day incubation period. 


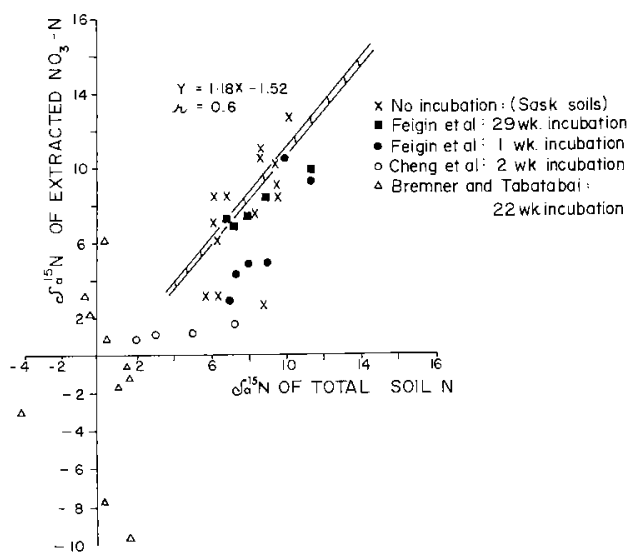

Fig. 1. The relationship between the $\delta_{\mathrm{a}}{ }^{15} \mathrm{~N}$ of total soil $\mathrm{N}$, and of $\mathrm{NO}_{3}-\mathrm{N}$ extracted from nonincubated samples; data from other workers is plotted for ready comparisons only, and not reflected in the regression line.

did not differ appreciably from that produced during a 21-day incubation period. This lack of agreement is significant in view of the intensive vs. extensive soil management practices (i.e. high vs. very low fertilizer $\mathrm{N}$ inputs) in the Midwest and Great Plains regions, respectively.

\section{Variations with Depth}

Only slight variations were recorded in the isotopic composition of the total $\mathrm{N}$ from the $\mathrm{A}, \mathrm{B}$ and upper $\mathrm{C}$ horizons of $\mathrm{a}$ Chernozemic profile (Table 3); the $\mathrm{C}$ horizon was not reached with the depth sampled for the Luvisolic. The ${ }^{15} \mathrm{~N}$ abundance was generally greatest at a depth of approximately $45 \mathrm{~cm}$.

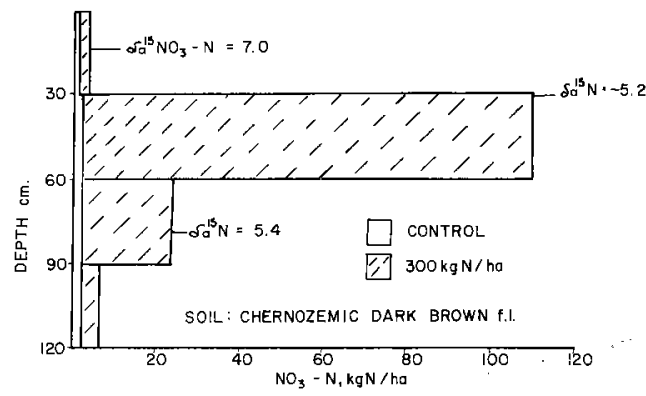

Fig. 2. $\mathrm{NO}_{3}-\mathrm{N}$ profile (mean of replicates) on fertilized $\left(\mathrm{NH}_{4} \mathrm{NO}_{3}\right)$ and control plots of an irrigated wheat experiment following harvest in September 1972 . The $\delta_{a}{ }^{15} \mathrm{~N}$ values were measured only on one of the six replicates.

The profile recorded in Table 4 was taken to a much greater depth. The significance of the modest decrease in $\delta_{\mathrm{a}}{ }^{15} \mathrm{~N}$ of total $\mathrm{N}$ at the 120- to 180-cm depth and the very sharp decrease in ${ }^{15} \mathrm{~N}$ abundance for $\mathrm{NO}_{3}-\mathrm{N}$ at this depth must await further investigation. The field has traditionally been in a 2-yr fallow-crop rotation, and substantial quantities of $\mathrm{NO}_{3}-\mathrm{N}$ were found both in the rooting zone ( $85 \mathrm{~kg} \mathrm{~N} / \mathrm{ha}$ ) and below the rooting zone to a depth of $3.6 \mathrm{~m}(382 \mathrm{~kg}$ $\mathrm{N} / \mathrm{ha}$ ). The majority of this nitrogen has been derived from mineralization of soil organic matter; as far as is known, the farm field from which the samples were taken has not received any fertilizer nitrogen.

\section{Fertilizer $\mathbf{N}$}

The residual $\mathrm{NO}_{3}-\mathrm{N}$ in the $0-$ to $120-\mathrm{cm}$ profile of two irrigated field fertilizer treatments receiving 0 and $300 \mathrm{~kg} \mathrm{~N} / \mathrm{ha}$ of $34-0-0$ is illustrated in Fig. 2. Substantial

Table 3. Total $\mathrm{N}$ and $\delta_{\mathrm{a}}{ }^{15} \mathrm{~N}$ for two soil profiles

\begin{tabular}{lcccc}
\hline & \multicolumn{2}{c}{$\begin{array}{c}\text { Chernozemic } \\
\text { Brown hvc }\end{array}$} & \multicolumn{2}{c}{$\begin{array}{c}\text { Luvisolic } \\
\text { Dark Grey 1 }\end{array}$} \\
\cline { 2 - 5 } $\begin{array}{l}\text { Depth } \\
(\mathrm{cm})\end{array}$ & $\begin{array}{c}\text { Total } \mathrm{N} \\
(\mu \mathrm{g} / \mathrm{g})\end{array}$ & $\delta_{\mathrm{a}}{ }^{15} \mathrm{~N}$ & $\begin{array}{c}\text { Total N } \\
(\mu \mathrm{g} / \mathrm{g})\end{array}$ & $\delta_{\mathrm{a}}{ }^{15} \mathrm{~N}$ \\
\hline $0-15$ & 2,220 & 6.4 & 2,150 & 4.6 \\
$15-30$ & 1,500 & 6.8 & 1,240 & 4.9 \\
$30-45$ & 1,200 & 7.1 & 830 & 6.0 \\
$45-60$ & 1,170 & 6.4 & 780 & 6.2 \\
$60-75$ & 990 & 6.1 & 620 & 5.6 \\
\hline
\end{tabular}


Table 4. $\quad \delta_{\mathrm{a}}{ }^{1 \overline{1}} \mathrm{~N}$ values at various depths

\begin{tabular}{|c|c|c|c|c|}
\hline \multirow{3}{*}{$\begin{array}{l}\text { Depth } \\
(\mathrm{cm})\end{array}$} & \multicolumn{4}{|c|}{ Chernozemic Dark Brown c } \\
\hline & \multicolumn{2}{|c|}{ Total N } & \multicolumn{2}{|c|}{$\mathrm{NO}_{3}-\mathrm{N}$} \\
\hline & $\mu \mathrm{g} / \mathrm{g}$ & $\delta_{\mathrm{a}}{ }^{15} \mathrm{~N}$ & $\mu \mathrm{g} / \mathrm{g}$ & $\delta_{\mathrm{a}}^{15 \mathrm{~N}}$ \\
\hline $0-15$ & 1,990 & 8.7 & 23 & 11.0 \\
\hline $15-120$ & 640 & 6.1 & 22 & 8.5 \\
\hline $120-150$ & 670 & 6.4 & 22 & 3.1 \\
\hline $150-180$ & 350 & 5.7 & 23 & 3.1 \\
\hline $180-240$ & 540 & 6.3 & 31 & 6.2 \\
\hline $240-270$ & 440 & 6.9 & 45 & 8.5 \\
\hline
\end{tabular}

amounts of the $300 \mathrm{~kg} \mathrm{~N} /$ ha rate of application were concentrated in the 30- to $60-\mathrm{cm}$ depth following harvest in 1972. Of interest is the very low $\delta_{\mathrm{a}}{ }^{15} \mathrm{~N}$ which characterized the nitrate $\mathrm{N}$ at this depth in comparison to that of the 0 - to $30-\mathrm{cm}$ depth.

The $\delta_{\mathrm{a}}{ }^{15} \mathrm{~N}$ of the $\mathrm{NH}_{4}-\mathrm{N}$ in a selected number of commercial fertilizers (Table 5) was consistently lower than for the $\mathrm{NO}_{3}-\mathrm{N}$, but in no instance were highly negative values obtained as reported by Freyer and Aly (1974); the heavier ${ }^{15} \mathrm{~N}$ isotope has obviously not been discriminated against during ammonia synthesis. From the assay of fertilizer-N samples reported in this study and those reported elsewhere (Freyer and Aly 1974; Shearer et al. 1974; Hauck 1973), the percent abundance of ${ }^{15} \mathrm{~N}$ in both the $\mathrm{NH}_{4}{ }^{+}$and $\mathrm{NO}_{3}{ }^{-}$ion species can be expected to vary widely. This observation negates the possibility of relating variation in ${ }^{15} \mathrm{~N}$ abundance of inorganic or organic soil- $\mathrm{N}$ to past fertilizer $\mathrm{N}$ practice.

\section{$\delta_{\mathrm{a}}{ }^{15} \mathrm{~N}$ of Crop Samples}

Preliminary results of $\delta_{\mathrm{a}}{ }^{15} \mathrm{~N}$ measurement on two crops, faba bean (Vicia faba) and barley (Hordeum vulgare), grown on a Chernozemic Black Loam soil (Table 6) suggest that though the differences are small in terms of absolute magnitude, it may be possible to extend field tracer methodology from its present dependence on enriched nitrogen to utilizing existing variations in natural abundance.

The ${ }^{15} \mathrm{~N}$ excess of the barley samples is significantly less than that of the soil $\mathrm{N}$ from which the plant derived its total $\mathrm{N}$ requirements. The $\delta_{\mathrm{a}}{ }^{15} \mathrm{~N}$ data for the faba bean, in contrast to the barley, reflect, in addition to discrimination against the heavier isotope during nitrification and plant uptake, the effect of symbiotic nitrogen fixation. If it is assumed that the beans derive their nitrogen from two sources, namely the air and the soil, it should be possible to apply the usual

Table 5. $\quad \delta_{\mathbf{a}}{ }^{15} \mathrm{~N}$ values for selected fertilizers

\begin{tabular}{lcccc}
\hline & & & \multicolumn{2}{c}{${ }^{15} \mathrm{~N}$ values $\dagger$} \\
\cline { 3 - 4 } Brand & Formulation & Compound & $\mathrm{NH}_{4}-\mathrm{N}$ & $\mathrm{NO}_{3}-\mathrm{N}$ \\
\hline 1 & $34-0-0$ & $\mathrm{NH}_{4} \mathrm{NO}_{3}$ & -0.6 & 3.6 \\
2 & $34-0-0$ & $\mathrm{NH}_{4} \mathrm{NO}_{3}$ & 1.0 & 4.8 \\
3 & $21-0-0$ & $\left.\mathrm{NH}_{4}\right)_{2} \mathrm{SO}_{4}$ & 4.8 & - \\
4 & $11-55-0$ & $\mathrm{NH}_{4} \mathrm{H}_{2} \mathrm{PO}_{4}$ & 1.3 & - \\
& & Average & 1.6 & 4.2
\end{tabular}

$\dagger$ Mean of three determinations. The mean standard deviation of measurement was $\pm .00031 \%$ abundance. 
Table 6. Variations in ${ }^{15} \mathrm{~N}$ in grain and straw of crops grown on a Chernozemic Black soil $\dagger$

\begin{tabular}{|c|c|c|}
\hline Crop & ${ }^{15} \mathrm{~N}$ excess & $\delta_{\mathrm{a}}{ }^{15} \mathrm{~N}$ \\
\hline $\begin{array}{l}\text { Faba bean } \\
\quad \text { (no fertilizer) }\end{array}$ & $\begin{array}{l}.00056 \\
.00035\end{array}$ & $\begin{array}{l}1.5 \pm 0.5 \\
1.0 \pm 0.5\end{array}$ \\
\hline $\begin{array}{l}\text { Faba bean } \\
\qquad\left(60 \mathrm{~kg} \mathrm{P} / \text { ha of } \mathrm{NH}_{4} \mathrm{H}_{2} \mathrm{PO}_{4}\right) \text { - grain } \\
\text { - straw }\end{array}$ & $\begin{array}{l}.00059 \\
.00024\end{array}$ & $\begin{array}{l}1.6 \pm 0.5 \\
0.7 \pm 0.2\end{array}$ \\
\hline $\begin{array}{ll}\text { Barley } & - \text { grain } \\
\left(60 \mathrm{~kg} \mathrm{P} / \mathrm{ha} \text { of } \mathrm{NH}_{4} \mathrm{H}_{2} \mathrm{PO}_{4}\right) & - \text { straw }\end{array}$ & $\begin{array}{l}.00153 \\
.00134\end{array}$ & $\begin{array}{l}4.2 \pm 0.5 \\
3.7 \pm 0.6\end{array}$ \\
\hline $\begin{array}{l}\text { Soil (total N) } \\
\mathrm{NH}_{4} \mathrm{H}_{2} \mathrm{PO}_{4}\end{array}$ & $\begin{array}{l}.00271 \\
.00048\end{array}$ & $\begin{array}{l}7.4 \pm 2.0 \\
1.3 \pm 1.7\end{array}$ \\
\hline
\end{tabular}

†The data are the mean of six replicates.

$\neq \%$ abundance (crop) $-0.3663\left(\mathrm{~N}_{2}\right.$ standard).

isotope dilution principle to estimate the amount of nitrogen in the faba bean that has come from the soil, i.e. $.00059 / .00153 \times$ $100 \approx 38 \%$ of the nitrogen in the bean has come from the soil, with the remainder, $62 \%$, from symbiotic $\mathrm{N}$ fixation. In this calculation, the ${ }^{15} \mathrm{~N}$ excess for the barley rather than the soil was utilized. This assumes equal discrimination in the uptake of ions by both crops.

\section{CONCLUSIONS}

The controversy in the literature concerning the application of natural ${ }^{15} \mathrm{~N}$ abundance to fertilizer $\mathrm{N}$ disposition studies has, to some extent, been resolved by the paper of Meints et al. 1975. They concluded that in relation to fertilizer $\mathrm{N}$ studies, the method of using natural variations in abundance of ${ }^{15} \mathrm{~N}$ is qualitative or, at best, roughly quantitative. The data reported in this manuscript suggest that the ${ }^{15} \mathrm{~N}$ fractions associated with fertilizer $\mathrm{N} \times$ soil reactions is complex, with both biological and physical fractionations occurring. At this time, the use of fertilizer $\mathrm{N}$ enriched with ${ }^{15} \mathrm{~N}$ offers major advantages over dependence on natural ${ }^{15} \mathrm{~N}$ variations.

There are a number of instances where normal tracer techniques using enriched ${ }^{15} \mathrm{~N}$ cannot readily be applied, but where variations in natural ${ }^{15} \mathrm{~N}$ abundance offer promise. Our data suggest that this includes the measurements of field $\mathrm{N}$ fixation integrated over a whole growing season, and the assessment of the fate of mineral nitrogen, derived from soil organic matter, which has accumulated below the rooting depth in semiarid environments such as the soils in the Great Plains Region.

An important parameter affecting the interpretations that can be made from measured natural variations in ${ }^{15} \mathrm{~N}$ in any compartment of an ecosystem is the errors associated with such analyses. The mass spectrometer has adequate accuracy, as measurements of ${ }^{15} \mathrm{~N}$ abundance can be made with a standard deviation of 0.2 $\delta_{\mathrm{a}}{ }^{15} \mathrm{~N}$. This is equivalent to $5 \%$ or less of the small differences in natural ${ }^{15} \mathrm{~N}$ abundances. In our measurements of the ${ }^{15} \mathrm{~N}$ abundance of plant $N$ in faba beans and barley, a standard deviation of $\pm 0.5 \delta_{\mathrm{a}}{ }^{15} \mathrm{~N}$ over a difference of 3 to $4 \delta_{\mathrm{a}}{ }^{15} \mathrm{~N}$ was encountered. This level of error includes instrument as well as soil variability.

Many $\mathrm{N}$ transformations in nature have not, in the past, been measured within an order of magnitude, and normal tracer techniques using ${ }^{15} \mathrm{~N}$ enrichment are often not applicable. Under such conditions, even though the use of natural ${ }^{15} \mathrm{~N}$ abundance must be termed somewhat speculative, it should lead to a better understanding of the nitrogen transfer between various compartments of the nitrogen cycle, and transformation rates in natural and man-made ecosystems. 
BREMNER, J. M. 1965. Isotope ratio analysis in $\mathrm{N}-15$ studies. In C. A. Black, ed. Methods of soil analysis, Part 2. Agronomy 9: 1282-1283.

BREMNER, J. M. and KEENEY, D. R. 1966. Determination and isotope-ratio analysis of different forms of nitrogen in soils. 3 . Exchangeable ammonium, nitrate, and nitrite by extraction-distillation methods. Soil Sci. Soc. Amer. Proc. 30: 577-582.

BREMNER, J. M., CHENG, H. H. and EDWARDS, A. P. 1966. Assumptions and errors in nitrogen-15 tracer research. Pages 429-445 in The use of isotopes in soil organic matter studies. Pergamon Press, New York, N.Y.

BREMNER, J. M. and TABATABAI, M. A. 1973. Nitrogen-15 enrichment of soils and soil-derived nitrate. J. Environ. Qual. 2: 263-365.

CAMPBEl_L, C. A., PAUL, E. A., RENNIE, D. A. and MCCALLUM, K. J. 1967. The applicability of the carbon-dating method of analysis to soil humus studies. Soil Sci. 104: $217-224$

CHENG, H. H., BREMNER, J. M. and EDWARDS, A. P. 1964. Variations of nitrogen-15 abundance in soils. Science 146: 1574-1575.

CLINE, J. D. 1973. Denitrification and isotopic fractionation in two contrasting marine environments: The Eastern tropical and North Pacific Ocean and the Cariaco trench. Ph.D. thesis, University of California, Los Angeles, Calif. CRAIG, H. 1957. Isotopic standards for carbon and oxygen and correction factors for mass spectrometric analysis of carbon dioxide. Geochim. Cosmochim. Acta 12: 133-148.

DELWICHE, C. C. and STEYN, P. L. 1970. Nitrogen isotope fractionation in soils and microbial reactions. Environ Sci. Technol. 4: 929-935.

EDWARDS, A. P. 1973. Isotope tracer techniques for identification of sources of nitrate pollution. J. Environ. Qual. 2: 382-387.

FEIGIN, A., SHEARER, G. B., KOHL, D. H. and COMMONER, B. 1974a. The amount and nitrogen-15 content of nitrate in soil profiles from two central Illinois fields in a corn- soybean rotation. Soil Sci. Soc. Amer. Proc. 38: 465-471.

FEIGIN, A. D., KOHL, D. H., SHEARER, G. B. and COMMONER, B. 1974b. Variations on the natural nitrogen-15 abundance in nitrate mineralized during incubation of several Illinois soils. Soil Sci. Soc. Amer. Proc. 38: 90-95.

FREYER, H. D. and ALY, A. I. M. 1974. Nitrogen- 15 variations in fertilizer nitrogen. J. Environ. Qual. 3: 405-406.

HAUCK, R. D. 1973. Nitrogen tracers in nitrogen cycle studies. Past use and future needs. J. Environ. Qual. 2: 317-327.

HOERING, T. C. 1955. Variations of nitrogen-15 abundance in naturally occurring substances. Science 122: 1233-1234.

JUNK, G. and SVEC, H. J. 1958. The absolute abundance of the nitrogen isotopes in the atmosphere and compressed gas from various sources. Geochim. Cosmochim. Acta 14: 234-243

KOHL, D. H., SHEARER, G. B. and COMMONER, B. 1971. Fertilizer nitrogen: Contribution to nitrate in surface water in a corn-beet watershed. Science 174: 1331-1334.

MEINTS, V. W., SHEARER, G., KOHL, D. H. and KURTZ, L. T. 1975. A comparison of unenriched versus ${ }^{15} \mathrm{~N}$-enriched fertilizer as a tracer for $\mathrm{N}$ fertilizer uptake. Soil Sci. 119: 421-425.

RENNIE, D. A. and PAUL, E. A. 1971. Isotope methodology and techniques in soil-plant nutrition and plant physiology. Sask. Inst. Pedol. Publ. 76, University of Saskatchewan Press. $142 \mathrm{pp}$

RIGA, A., VAN PRAAG, H. J. and BRIGODE, N. 1971. Rapport isotopique naturel de l'azote dans quelques sols forestiers et agricoles de Belgique soumis à divers traitements culturaux. Geoderma 6: 213-222.

SHEARER, G. B., KOHL, D. H. and COMMONER, B. 1974. The precision of determination of the natural abundance of nitrogen-15 in soils, fertilizers and sheef chemicals. Soil Sci. 118: 308-316.

WELLMAN, B. P., COOK, F. O. and KROUSE, H. R. 1968. Nitrogen-15: Microbial alteration of abundance. Science 161: 269-270. 